\title{
Parental Communication Increases Student Learning Motivation in Elementary Schools
}

\section{Alfauzan Amin ${ }^{1 *}$, Alimni ${ }^{2}$, Dwi Agus Kurniawan ${ }^{3}$, Miftahul Zannah Azzahra ${ }^{4}$, Sabila Eka Septi ${ }^{5}$}

1,2 Faculty of Tarbiyah and Tadris, Universitas Islam Negeri Fatmawati Sukarno , Bengkulu, Indonesia

3,4,5 Faculty of Teaching and Education, Universitas Jambi, Jambi , Indonesia

\section{A R T I C L E I N F O}

\section{Article history:}

Received October 01, 2021

Revised October 02, 2021

Accepted November 14, 202

Available online November 25, 2021

\section{Kata Kunci:}

Pendidikan Agama Islam,

Komunikasi, Motivasi

Keywords:

Islamic Religious Education, Communication, Motivation

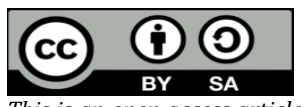

This is an open access article under the $\underline{C C}$ BY-SA license.

Copyright (C) 2021 by Author. Published by Universitas Pendidikan Ganesha.

\begin{abstract}
A B S T R A K
Masih kurangnya komunikasi orangtua terhadap motivasi belajar siswa di tingkat sekolah dasar. Hal ini berdampak pada tingkat motivasi belajar siswa yang kurang. Penelitian ini bertujuan untuk menganalisis komunikasi orangtua terhadap motivasi belajar siswa dalam proses pembelajaran pendidikan agama Islam. Jenis penelitian ini adalah metode campuran yaitu kuantitatif dan kualitatif dengan desain explanatory. Subjek dalam penelitian ini adalah orangtua dan siswa SD. Teknik pengumpulan data yang digunakan dalam penelitian ini yaitu distribusi kuesioner dan wawancara. Metode analisis data yang digunakan adalah analisis deskriptif kuantitatif dengan menguji hasil temuan menggunakan spps; mencatat hasil; dan membuat kesimpulan. Deskripsi kuantitatif dengan menyebarkan kuesioner dan melakukan wawancara. Hasil penelitian menunjukkan bahwa terdapat perbedaan dan pengaruh antara komunikasi orangtua dengan motivasi belajar siswa pada mata pelajaran pendidikan agama Islam. Jadi, dapat disimpulkan bahwa komunikasi orangtua terhadap motivasi belajar siswa sudah dilaksanakan dengan sangat baik walaupun belum maksimal. Komunikasi orang tua sudah dilakukan dengan baik sehingga motivasi belajar siswa juga akan meningkat dan berdampak pada peningkatan disiplin belajar siswa.
\end{abstract}

\begin{abstract}
A B S T R A C T
There is still a lack of parental communication on students' learning motivation at the elementary school level. It has an impact on the level of student learning motivation that is less. This study aims to analyze parental communication on students' learning motivation in the learning process of Islamic religious education. This type of research is a mixedmethod, namely quantitative and qualitative with an explanatory design. The subjects in this study were parents and elementary students. Data collection techniques used in this study were the distribution of questionnaires and interviews. The data analysis method used is a quantitative descriptive analysis by testing the findings using apps, record results, and concluding. Quantitative description by distributing questionnaires and conducting interviews. The results showed differences and influences between parental communication and student learning motivation in Islamic religious education subjects. So, it can be concluded that parental communication on student learning motivation has been carried out very well, although not optimally. Parental communication has been done well so that students' learning motivation will also increase and impact increasing student learning discipline.
\end{abstract}

\section{INTRODUCTION}

21st-century learning, known as the knowledge age, is everything that can be knowledge-based (B. Anwar \& Asriani, 2017; Gelen Assoc, 2018). 21st-century learning focuses on thinking skills, solving problems, and communicating to create fun learning (Boraya, 2018; Benbow et al., 2021; Junedi et al., 2020). In the 21st century, education is essential to motivate students to learn. The need for knowledge in the 21st century occurs when there are four pillars of education: learning to know, learning to do, learning to be, and living (Chai \& Kong, 2017; Gürsoy, 2021; Wegawati et al., 2016). The relationship between 21stcentury learning is very closely related to the world of education. Education is learning intending to gain knowledge and skills and everything that will be learned and needed in the future (Delaney et al., 2020; Ferreira et al., 2018; Speight et al., 2018). The purpose of education is to direct students to become human beings who know, have a noble character, and become citizens who obey the rules, are democratic, and have a sense of responsibility (Lestari et al., 2021; Mason, 2020). Therefore, to improve the quality of education, it can be done starting from the elementary school level, which is carried out based on the needs of students (Kalaw, 2017; Șemin, 2019). Education in Indonesia, one of which is the elementary school level, where at 
this level, education is needed in order to continue to a higher level, namely the secondary level. If education at the elementary school level can be reached, it will be easier for students to continue with higher education.

Elementary school is a crucial formal education in Indonesia and is carried out for six years (Kamar et al., 2020; Setyani et al., 2021). Primary schools generally only learn basic concepts, namely general knowledge suitable for students aged six to twelve years (Century et al., 2020; Hidayati et al., 2017; Kjeldsen, 2019). Education in primary schools aims to build a knowledge base and cultivate students' intelligence and skills (Anif et al., 2020; Kjeldsen, 2019; Zarić et al., 2021). An elementary school is also a place where children learn to play and grow their motivation to learn. In fostering student learning motivation at the elementary school level, ineffective Islamic religious subjects are very effective. Islamic religious education is essential in forming one's character (Abdussalam et al., 2019; C. Anwar et al., 2018; Fathul Amin, 2019). The Islamic Education curriculum is an essential component of shaping character and creating a generation of noble character and martyrdom (Arsyad et al., 2020; Maas, 2019; Utari et al., 2020). This Islamic religious education expects people who already know about its teachings and practices in everyday life. The purpose of Islamic religious education is oriented to human self-development, developing the abilities, knowledge, and skills of students to praise God and achieve happiness in the world and salvation in the universe (Saada \& Magadlah, 2021; Ulfat, 2020). Educating children with Islamic education is the responsibility of parents. No matter how busy parents are, education for children is better, especially religious education.

Communication is a process of passing symbols from the source to the recipient (Neveu et al., 2017; Nisa \& Sujarwo, 2020; Oktarina \& Abdullah, 2017). Teachers and parents have the same educational goal of nurturing, educating, guiding, and leading their children. Parental communication is also essential in ensuring that children's learning is successful. Encouraging teacher-parent communication is essential. Teacher-parent communication significantly impacts student learning, performance, and behavior (Garbacz et al., 2015; Gisewhite \& Holden, 2019; Kraft \& Rogers, 2015). Effective communication can ensure optimal interaction between teachers, students, and parents and can help regulate the roles of families and teachers and support in determining student needs (Özkan Yıldız \& Yllmaz, 2021; Triwardhani et al., 2020). With pleasant parent-student communication, it is possible to increase student learning motivation at school and home. However, the current problem is the lack of communication between parents and their children (Nursaptini et al., 2020; Sumarsono et al., 2019). Hal tersebut akan berdampak pada motivasi belajar siswa yang berkurang sehingga menyebabkan menurunkan hasil belajar siswa (Özkan Yıldız \& Yılmaz, 2021; Wang, 2020). Student learning motivation is one of the techniques in developing the ability and willingness to learn. Student learning outcomes are influenced by many factors, including student motivation, students who have profound learning motivation and are interested in learning to get satisfactory learning outcomes. Without motivation, the learning process will be challenging to achieve optimal success (Fauziah et al., 2017; Ricardo \& Meilani, 2017; Pratama et al., 2019). Extrinsic motivation arises from external influences from individuals, such as orders and even coercion from others so that students will do something (Daniati et al., 2020; Hornstra et al., 2018; Winata et al., 2019). While motivation is determined by participation in seeking pleasure, the goal in which the activity itself becomes to increase student motivation (Aprilia et al., 2020; Demirdağ, 2021; Franco et al., 2019). Motivation to learn in students must be increased so that they can participate in learning enthusiastically to get satisfactory results.

This research is in line with previous research that said that parents influence students' learning motivation to get good results (Andriani \& Rasto, 2019; Rosmalina \& Zulyanty, 2019). However, the previous research did not compare the two schools and did not conduct interviews with children directly to know the comparison and how much influence parental communication had on learning motivation (Andriani \& Rasto, 2019; Rosmalina \& Zulyanty, 2019). Moreover, several indicators and interviews with students to determine how much influence communication had-parents on student learning in Islamic religious lessons in elementary school. The urgency in this study is critical because it is rare to find research that examines parental communication and student motivation in elementary school. In addition, this study also seeks to see the importance of parental communication and student learning motivation in Islamic religious education subjects in elementary schools by looking at the importance of parental communication and student learning motivation from questionnaires and interviews. The purpose of this study was to analyze how crucial parental communication and learning motivation is in Islamic religious education subjects in elementary schools seen from descriptive statistics. Moreover, to find out whether there are differences in parental communication that affect student learning communication as seen from testing assumptions and The hypotheses and results of this study can be helpful for parents and students. If parental communication is poor, it can have a significant effect on student success in learning. Therefore, this research was conducted to find out this purpose. 


\section{METHOD}

This research uses mixed research methods with explanatory design. Mixed methods research is research that combines quantitative research methods and qualitative research methods (Plano Clark, 2017). Explanatory design can be carried out in several stages of research, starting from collecting data, analyzing data and formulating quantitative results, followed by collecting data, analyzing and formulating qualitative data, and ending with interpreting the results of the research. The instrument in this study used 2 types of instruments, namely questionnaires and interviews. The questionnaire used consisted of a parent communication questionnaire and a student learning motivation questionnaire. As well as interviews conducted on students. There are 11 valid statement items on this parental communication instrument variable using a Likert scale. The scale consists of 4 points with a very appropriate score of 4 very not good, 3 not good, 2 good, 1 very good. Each statement is representative of Each parent communication Indicator. There are 8 valid statement items on the variable of student learning motivation. Later indicators used to measure parental communication are positive feelings and support. In the variable of student learning motivation, two indicators are used, namely persistence in learning and independent learning. The description of the lattice of the questionnaire instrument for parental communication and student learning motivation in Islamic religious education subjects in tabel 1.

Table 1. Description of parental communication and student learning motivation in Islamic religious education subjects

\begin{tabular}{lll}
\hline \multicolumn{1}{c}{ Variable } & \multicolumn{1}{c}{ Indicator } & \multicolumn{1}{c}{ Statement Item Number } \\
\hline Parental communication & Positive feelings & 1.2 .3 .4 \\
& Endorsement & 5.6 .7 .8 .9 .10 .11 \\
student's motivation to study & Perseverance in learning & 1.2 .3 .4 \\
& Independent in learning & 5.6 .7 .8 \\
\hline
\end{tabular}

Due to the parental communication questionnaire and student learning motivation in Islamic religious education subjects using a Likert scale consisting of 4 categories, there are intervals in each category, and the intervals in each category can be seen in table 2 .

Table 2. Categories of parental communication communication and student motivation in Islamic religious education subjects

\begin{tabular}{ccccc}
\hline \multirow{3}{*}{ Category } & \multicolumn{4}{c}{ Indicator Interval } \\
\cline { 2 - 5 } & \multicolumn{2}{c}{ Parent communication } & \multicolumn{2}{c}{ Student learning motivation } \\
\cline { 2 - 5 } & $\begin{array}{c}\text { Positive } \\
\text { feelings }\end{array}$ & Support & $\begin{array}{c}\text { Perseverance in } \\
\text { learning }\end{array}$ & $\begin{array}{c}\text { Independent in } \\
\text { learning }\end{array}$ \\
\hline Very not good & $4.0-7.0$ & $7.0-12.25$ & $4.0-7.0$ & $4.0-7.0$ \\
Not good & $8.0-10.0$ & $12.35-17.50$ & $8.0-10.0$ & $8.0-10.0$ \\
Good & $11.0-13.0$ & $17.60-22.75$ & $11.0-13.0$ & $11.0-13.0$ \\
Very good & $14.0-16.0$ & $22.85-28.0$ & $14.0-16.0$ & $14.0-16.0$ \\
\hline
\end{tabular}

The research population and sample are research conducted with characteristics and other things that will be needed in a study (Erba et al., 2018). The population in this study were 80 students consisting of 40 elementary school students 9 Bengkulu City and 40 elementary school students 9 Jambi City. The sampling technique is total sampling. The subjects taken were classes VA and VB which consisted of 20 women and 20 men. The reason for taking research subjects from classes VA and VB is that at the elementary school level, the class level is very effective, judging from the communication between parents and the student's learning motivation. The data analysis technique used was random sampling because the samples used were elementary school students 9 Bengkulu City and elementary school students 9 Jambi City who studied Islamic religious education subjects according to the variables of parental communication and student motivation. The use of random sampling in this research is to save time, cost and effort, and also allows the results of the research to be more precise and thorough, because all data from the research object will be easier to analyze in detail. The sampling technique was taken because the parameter assessment was unbiased and better if the population was homogeneous (Alsabahi et al., 2021). From this data, descriptive statistical testing is then carried out. In this study, the researcher used the mean, median, min and max to find out information based on descriptive statistics. and inverential tests in the form of testing assumptions and hypotheses. In the assumption test, three tests were carried out, namely normality test, linearity test, and homogeneity test. The normality test is used to test whether the data is normally 
distributed or not (Saerang et al., 2014). Terms of the data are said to be normally distributed if the value of sig. $>0.05$. Linearity test is a test used to determine the form of the relationship between independent variables or variables. The data requirements are said to be related if the value of sig. $<0.05$. Homogeneous test works to find out whether several groups of research data have the same variance or not, the condition is that the data is said to be homogeneous if the value of sig.> 0.05 . Then test the hypothesis in the form of $t$ test and regression test. The t-test works to determine the parental communication variables on students' learning motivation. Regression test works to determine the effect of parental communication on student motivation. These tests were then tested using SPSS 26 to obtain accurate results.

In collecting data, the first activity that must be done is to select students based on the categories given by the researcher, then provide questionnaires and interviews about parental communication and student learning motivation. This questionnaire was addressed to students in Elementary School 9 Bengkulu City and Elementary School 9 Jambi City, namely 80 students who became subjects in this study, which aims to determine the effect of parental communication on learning motivation. Then the questionnaire data was processed using the SPSS application. The use of the SPSS application functions to view descriptive statistics, in the form of mean, min, max, percentage, and category of students (Pramesti, 2018; Santoso, 2019). The data needed in research can be collected or obtained from various data sources.

\section{RESULT AND DISCUSSION}

\section{Result}

The following describes the results of descriptive statistics on parental communication variables and student learning motivation. With questions about indicators of parental communication: positive feelings and support. Indicators of student learning motivation: perseverance in learning and independence in learning. The results were obtained from the distribution of questionnaires and interviews in elementary schools 9 Bengkulu City and 9 Jambi City. The results of statistical tests obtained, the average number of students chose the good category with the percentage for elementary school 9 Bengkulu City 35\% good and elementary school 9 Jambi City $45 \%$ good. So it can be said that the Jambi City 9 Elementary School is superior to the Bengkulu City 9 Primary School in the positive feeling indicator. Based on table 4, the average number of students chose the good category with the percentage for elementary school 9 Bengkulu City $45 \%$ good and 9 Jambi City 50\% good. The comparison with Elementary School 9 Jambi City is higher than Elementary School 9 Bengkulu City, so it can be said that Elementary School 9 Jambi City is superior to elementary school 9 in Bengkulu City in the positive feeling indicator.

The average number of students chose the good category with the percentage for elementary school 9 Bengkulu City 35\% good and 9 Jambi City 40\% good. So, the Jambi City 9 Elementary School is superior to the Bengkulu City 9 Primary School in perseverance in learning. The comparison with Elementary School 9 Jambi City is higher than Elementary School 9 Bengkulu City, so it can be said that Elementary School 9 Jambi City is superior to elementary school 9 in Bengkulu City in the empathy indicator. The comparison with Elementary School 9 Jambi City is higher than Elementary School 9 Bengkulu City, so it can be said that Elementary School 9 Jambi City is superior to elementary school 9 in Bengkulu City in perseverance in learning. The average number of students chose the good category with the percentage for elementary school 9 Bengkulu City 25\% good and elementary school 9 Jambi City 25\% good. So it can be said that elementary school 9 Jambi City is the same as elementary school 9 Bengkulu City in independent indicators in learning. It can be seen that the comparison with Elementary School 9 Jambi City is higher than Elementary School 9 Bengkulu City, so it can be said that Elementary School 9 Jambi City is superior to elementary school 9 in Bengkulu City in independent indicators in learning.

The normality test results of parental communication and student motivation at elementary school 9 Bengkulu City obtained the value of sig. 0.692 and 0.784 , and in elementary schools 9 Jambi City 0.826 and 0.763 . it can be said that the results obtained $>0.05$, so it can be said that the data is usually distributed. The Kolmogorov-Smirnov test obtained the normality test. The significance value was $>$ from 0.05 . The results of the linearity test of parental communication and student learning motivation, namely in elementary school 9 Bengkulu City, namely 0.024 and 0.025 while at elementary school 9 Jambi City 0.048 and 0.049 , it can be said that the results obtained $<0.05$ so it can be said linear patterned data. It is proven that the result of sig is less than 0.05 . The homogeneity test results of parental communication and student motivation in elementary school 9 Bengkulu City are 0.037 and 0.038 , while at elementary school 9 Jambi City is 0.047 and 0.048 it can be said that the results obtained are $<0.05$, so it can be said that the data homogeneous. It is proven that the result of sig (2-tailed) is less than 0.05 .

The results of the t-test of parental communication and student learning motivation are at elementary school 9 in Bengkulu City, namely 0.036 and 0.037 , and at elementary school 9 Jambi City is 0.38 and 0.039 . so it can be ascertained that there is a comparison between elementary schools 9 Bengkulu City 
and elementary schools 9 Jambi City, as evidenced by sig results. (2-tails) $<0.05$. The results of the regression test of parental communication and learning motivation, namely in elementary school 9 Bengkulu City, namely 0.023 and at elementary school 9 Jambi City, namely 0.024 so it can be said that based on the influence on parental communication variables and student learning motivation in elementary school 9 City Bengkulu and elementary schools 9 Jambi City, as evidenced by the results of sig. $<0.05$.

\section{Discussion}

Parents are the primary and first educators for children. Thus the first form of education is in the family (Jannah \& Umam, 2021; Sukendar et al., 2019). In general, education in the household provides realistic possibilities for building educational situations (Churiyah et al., 2020; Kamar et al., 2020; Wiyani, 2020). The educational situation is realized thanks to the association and influence that affects reciprocity between parents and children. Parents play an important and influential role in children's education anak (Karima \& Kurniawati, 2020; Zijlstra et al., 2021). Parental education is based on affection for children (Junianto \& Wagiran, 2013; Setiawati et al., 2017). Therefore, parental love for children should be true love as well. The importance of parental communication and student motivation in Islamic religious education subjects will improve student learning outcomes (Simanjuntak et al., 2020; Triwardhani et al., 2020). This study is in line with previous research testing descriptive tests, but this study only discusses student learning motivation in science subjects, and also, this study only discusses learning motivation in general without using indicators (Pratama et al., 2019b). Based on interviews with students, most parents have positive feelings towards their children in learning, with parental communication very influential on children's learning motivation (Chen et al., 2019; Le et al., 2019; Tamboto et al., 2021). Some parents also pay attention to learning, and some pay less attention, and most of their parents have demanded that they be independent in learning, and some observe their children in learning.

This research is in line with previous research that parents have an essential role for every child, including role models, motivators, and initiators, and parents as a family have a role in every achievement obtained by a child (Andriani \& Rasto, 2019; Rosmalina \& Zulyanty, 2019). The findings of previous studies did not compare parental communication with learning motivation accurately because this study carried out several tests such as those carried out by this study, namely: T-test and regression test, where the function of the T-test was to determine the comparison of the two variables and the regression test to determine the effect of the two variables. Tested variables (Andriani \& Rasto, 2019; Rosmalina \& Zulyanty, 2019). With this study, the problem of parental communication and student motivation can be solved by giving more attention to students so that students learn in learning so that students can focus on learning and get good grades. Good in learning, students can also develop according to their talents because they get encouragement from their parents.

This research implies that parental communication is needed to shape students' learning motivation, and good parental communication can be applied to student learning outcomes, which will later be helpful for students' future. In this study, it was found that parental communication was excellent. This is very influential in growing the student learning communication of students in studying Islamic religious education (Fauziah et al., 2017; Pratama et al., 2019). Thus, parental communication can be carried out with excellent student learning communication for elementary school students. The limitation of this study is that it only compares the variables between parental communication and student learning motivation. However, it has not been tested with other variables such as teacher communication, where teacher communication is essential to know the comparison and influence of student learning communication on learning success. So that variables such as teacher communication are to be tested in further research. Researchers suggest conducting further research to compare the variables of parental communication and student learning motivation with other variables such as teacher communication, and researchers suggest researching at the elementary school level.

\section{CONCLUSION}

Student learning discipline is closely related to parental communication. Learning discipline is one form of fulfilling obligations so that changes occur in students. Parental communication has been done well so that students' learning motivation will also increase and impact increasing student learning discipline.

\section{REFERENCES}

Abdussalam, A., Anwar, S., \& Rahmat, A. T. (2019). The Development of Translation Capability for the Holy Quran of Student of Teacher Candidate for Islamic Religious Education: A Tamyiz Learning and Teaching Strategy. Hayula: Indonesian Journal of Multidisciplinary Islamic Studies, 3(1). 
https://doi.org/https://doi.org/10.21009/003.1.01.

Alsabahi, M. A., Maisurah, K., Bahador, K., \& Saat, R. M. (2021). Cogent Business \& Management The influence of personal characteristics and workplace learning on information technology competency among external auditors: The role of organisational culture as a moderator The influence of personal characteristics and wo. Cogent Business \& Management, 8(1). https://doi.org/10.1080/23311975.2021.1899625.

Andriani, R., \& Rasto, R. (2019). Motivasi belajar sebagai determinan hasil belajar siswa. Jurnal Pendidikan Manajemen Perkantoran, 4(1), 80. https://doi.org/10.17509/jpm.v4i1.14958.

Anif, S., Sutopo, A., \& Prayitno, H. J. (2020). Lesson study validation: Model for social and natural sciences teacher development in the implementation of national curriculum in Muhammadiyah schools, Indonesia. Universal Journal of Educational Research, 8(1), 253-259. https://doi.org/10.13189/ujer.2020.080132.

Anwar, B., \& Asriani. (2017). Penerapan Pembelajaran Problem Solving untuk Meningkatkan Aktivitas dan Hasil Belajar Matematika pada Materi SPLDV. Jurnal Pendidikan Matematika, 4(2), 224-239. https://doi.org/10.36709/jpm.v4i2.2035.

Anwar, C., Saregar, A., Hasanah, U., \& Widayanti. (2018). The Effectiveness of Islamic Religious Education inthe Universities: The Effects on the Students' Characters in the Era of Industry 4.0. Tadris: Jurnal Keguruan Dan Ilmu Tarbiyah, 3(1), 77-87. https://doi.org/10.24042/tadris.v3i1.2162.

Aprilia, F., Lustyantie, N., \& Rafli, Z. (2020). The Effect of Reading Interest and Achievement Motivation on Students ' Discourse Analysis Competence. Journal of Education and E-Learning Research, 7(4), 368-372. https://doi.org/10.20448/journal.509.2020.74.368.372.

Arsyad, A., Sulfemi, W. B., \& Fajartriani, T. (2020). Penguatan Motivasi Shalat Dan Karakter Peserta Didik Melalui Pendekatan Pembelajaran Kontekstual Pada Mata Pelajaran Pendidikan Agama Islam. POTENSIA: Jurnal Kependidikan Islam, 6(2), 185. https: //doi.org/10.24014/potensia.v6i2.9662.

BAROYA, E. H. (2018). Strategi Pembelajaran Abad 21. As-Salam: Jurnal Ilmiah Ilmu-Ilmu Keislaman, I(01), $101-115$.

Benbow, R. J., Lee, C., \& Hora, M. T. (2021). Exploring college faculty development in 21st-century skill instruction: an analysis of teaching-focused personal networks. Journal of Further and Higher Education, 45(6), 818-835. https://doi.org/10.1080/0309877X.2020.1826032.

Century, J., Ferris, K. A., \& Zuo, H. (2020). Finding time for computer science in the elementary school day: a quasi-experimental study of a transdisciplinary problem-based learning approach. International Journal of STEM Education, 7(1). https://doi.org/10.1186/s40594-020-00218-3.

Chai, C. S., \& Kong, S.-C. (2017). Professional learning for 21st century education. Journal of Computers in Education, 4(1), 1-4. https://doi.org/10.1007/s40692-016-0069-y.

Chen, Y., Mayall, H. J., York, C. S., \& Smith, T. J. (2019). Parental perception and English Learners' mobileassisted language learning: An ethnographic case study from a technology-based Funds of Knowledge approach. Learning, Culture and Social Interaction, 22. https://doi.org/10.1016/j.lcsi.2019.100325.

Churiyah, M., Sholikhan, S., Filianti, F., \& Sakdiyyah, D. A. (2020). Indonesia Education Readiness Conducting Distance Learning in Covid-19 Pandemic Situation. International Journal of Multicultural and Multireligious Understanding, 7(6), 491. https://doi.org/10.18415/ijmmu.v7i6.1833.

Daniati, D., Ismanto, B., \& Luhsasi, D. I. (2020). Upaya Peningkatan Motivasi dan Hasil Belajar Mahasiswa dengan Penerapan Model Pembelajaran E-Learning Berbasis Google Classroom pada Masa Pandemi Covid-19. Jurnal Kependidikan: Jurnal Hasil Penelitian Dan Kajian Kepustakaan Di Bidang Pendidikan, Pengajaran Dan Pembelajaran, 6(3), 601. https://doi.org/10.33394/jk.v6i3.2642.

Delaney, C. W., AbuSalah, A., Yeazel, M., Stumpf Kertz, J., Pejsa, L., \& Brandt, B. F. (2020). National center for interprofessional practice and education IPE core data set and information exchange for knowledge generation. Journal of Interprofessional Care, 00(00), 1-13. https://doi.org/10.1080/13561820.2020.1798897.

Demirdağ, S. (2021). Communication Skills and Time Management as the Predictors of Student Motivation. International Journal of Psychology and Educational Studies, 8(1), 38-50. https://doi.org/10.17220/ijpes.2021.8.1.222.

Erba, J., Ternes, B., Bobkowski, P., Logan, T., \& Liu, Y. (2018). Sampling Methods and Sample Populations in Quantitative Mass Communication Research Studies: A 15-Year Census of Six Journals. Communication Research Reports, 35(1), https://doi.org/10.1080/08824096.2017.1362632.

Fathul Amin. (2019). Pembentukan Karakter Melalui Pendidikan Agama Islam. Tadris : Jurnal Penelitian Dan Pemikiran Pendidikan Islam, 12(2), 33-45. https://doi.org/10.51675/jt.v12i2.22.

Fauziah, A., Rosnaningsih, A., \& Azhar, S. (2017). Hubungan Antara Motivasi Belajar Dengan Minat Belajar 
Siswa Kelas IV SDN Poris Gaga 05 Kota Tangerang. JURNAL JPSD, Vol. 4 No, 47-53. https://doi.org/10.26555/jpsd.v4i1.a9594.

Ferreira, J., Behrens, M., Torres, P., \& Marriott, R. (2018). The necessary knowledge for online education: Teaching and learning to produce knowledge. Eurasia Journal of Mathematics, Science and Technology Education, 14(6). https://doi.org/10.29333/ejmste/86463.

Franco, E., Coterón, J., Huéscar, E., Antonio, J., \& Moreno Murcia. (2019). A person-centered approach in physical education to better understand low-motivation students. Journal of Teaching in Physical Education. https://doi.org/10.1123/jtpe.2019-0028.

Garbacz, S. A., Sheridan, S. M., Koziol, N. A., Kwon, K., \& Holmes, S. R. (2015). Congruence in parent-teacher communication: Implications for the efficacy of CBC for students with behavioral concerns. School Psychology Review, 44(2), 150-168. https://doi.org/10.17105/spr-14-0035.1.

Gelen Assoc, I. (2018). European Journal of Education Studies Academicians' Predictions Of 21 St Century Education And Education In The 21 St Century. 4, 165-204. https://doi.org/10.5281/zenodo.1233478.

Gisewhite, R. A., \& Holden, M. M. J. C. L. (2019). A call for ecologically-based teacher-parent communication skills training in pre-service teacher education programmes. Educational Review, 1-20. https://doi.org/https://doi.org/10.1080/00131911.2019.1666794.

Gürsoy, G. (2021). Digital storytelling: Developing 21st century skills in science education. European Journal of Educational Research, 10(1), 97-113. https://doi.org/10.12973/EU-JER.10.1.97.

Hidayati, N. A., Hendriati, N., Prasetyo, P., Putri, H. A., \& Maimunah, S. (2017). Pengembangan Inovasi Pembelajaran Berbasis Proyek Ilmiah dalam Meningkatkan Sikap terhadap Ilmu Pengetahuan Siswa SMP Kota Malang. Jurnal Konseling Dan Pendidikan, 5(2), 85. https://doi.org/10.29210/116600.

Hornstra, L., Kamsteeg, A., Pot, S., \& Verheij, L. (2018). A dual pathway of student motivation : Combining an implicit and explicit measure of student motivation. Frontline Learning Research, 6(1), 1-18. https://doi.org/10.14786/flr.v6i1.305.

Jannah, N., \& Umam, K. (2021). Peran Orang Tua dalam Pendidikan Karakter Berbasis Keluarga di Masa Pandemi Covid-19. FALASIFA: Jurnal Studi Keislaman, 12(1), 95-115. https://doi.org/10.36835/falasifa.v12i1.460.

Junedi, B., Mahuda, I., \& Kusuma, J. W. (2020). Optimalisasi keterampilan pembelajaran abad 21 dalam proses pembelajaran pada Guru MTs Massaratul Mut'allimin Banten. Transformasi: Jurnal Pengabdian Masyarakat, 16(1), 63-72. https://doi.org/10.20414/transformasi.v16i1.1963.

Junianto, D., \& Wagiran, W. (2013). Pengaruh kinerja mengajar guru, keterlibatan orang tua, aktualisasi diri dan motivasi berprestasi terhadap prestasi. Jurnal Pendidikan Vokasi, 3(3), 307-319. https: //doi.org/10.21831/jpv.v3i3.1845.

Kalaw, M. T. B. (2017). Trend of De La Salle Lipa Education Graduates' Performance in the Licensure Examination for Teachers (LET) from 2011 to 2015. International Journal of Evaluation and Research in Education (IJERE), 6(2), 138. https://doi.org/10.11591/ijere.v6i2.7592.

Kamar, K., Asbari, M., Purwanto, A., Nurhayati, W., \& Sudiyono, R. N. (2020). Membangun Karakter Siswa Sekolah Dasar Melalui Prakter Pola Asuh Orang Tua Berdasarkan Genetic Personality. Jurnal Inovasi Pembelajaran, 6(c), 75-86. https://doi.org/10.22219/jinop.v6i1.10196.

Karima, R., \& Kurniawati, F. (2020). Kegiatan Literasi Awal Orang Tua pada Anak Usia Dini. Al-Athfal : Jurnal Pendidikan Anak, 6(1), 69-80. https://doi.org/10.14421/al-athfal.2020.61-06.

Kjeldsen, K. (2019). A study-of-religion(S)-based religion education: Skills, knowledge, and aims. Center for Educational Policy Studies Journal, 9(4), 11-29. https://doi.org/10.26529/cepsj.678.

Kraft, M. A., \& Rogers, T. (2015). The underutilized potential of teacher-to-parent communication: Evidence from a field experiment. Economics of Education Review, 47, 49-63. https://doi.org/10.2139/ssrn.2528688.

Le, T. T. H., Tran, T., Trinh, T. P. T., Nguyen, C. T., Nguyen, T. P. T., Vuong, T. T., Vu, T. H., Bui, D. Q., Vuong, H. M., Hoang, P. H., Nguyen, M. H., Ho, M. T., \& Vuong, Q. H. (2019). Reading habits, socioeconomic conditions, occupational aspiration and academic achievement in Vietnamese junior high school students. Sustainability (Switzerland), 11(18), 1-29. https://doi.org/10.3390/su11185113.

Lestari, K. B., Dwi Lestari, I. F., \& Santoso, I. (2021). The Impact of Health Education Using Online Learning on Adolescent Knowledge of Anaemia. KnE Social Sciences, 2021, 209-220. https://doi.org/10.18502/kss.v5i3.8541.

Maas, P. H. (2019). Curriculum Development, Islamic Religious Education, Islamic Elementary School AL Azhar. Atthulab: Islamic Religion Teaching and Learning Journal, 4(1). https://doi.org/https://doi.org/10.15575/ath.v4i1.2850.

Mason, G. (2020). Higher education, initial vocational education and training and continuing education and 
training: where should the balance lie? Journal of Education and Work, 33(7-8), 468-490. https://doi.org/10.1080/13639080.2020.1755428.

Neveu, M. J., Jackson, D., Greene, D., White, M., Jones, W., Hight, C., \& Clouse, C. (2017). The Design of Environmetal Design. Journal of Architectural Education, 71(2), 135-286. https://doi.org/10.1080/10464883.2017.1409001.

Nisa, K., \& Sujarwo, S. (2020). Efektivitas Komunikasi Guru terhadap Motivasi Belajar Anak Usia Dini. Jurnal Obsesi : Jurnal Pendidikan Anak Usia Dini, 5(1), 229. https://doi.org/10.31004/obsesi.v5i1.534.

Nursaptini, N., Syazali, M., Sobri, M., Sutisna, D., \& Widodo, A. (2020). Profil Kemandirian Belajar Mahasiswa dan Analisis Faktor yang Mempengaruhinya: Komunikasi Orang Tua dan Kepercayaan Diri. Jurnal Pendidikan Edutama, 7(1). https://doi.org/10.30734/jpe.v7i1.711.

Oktarina, Y., \& Abdullah, Y. (2017). Komunikasi dalam perspektif teori dan praktik. Deepublish.

Özkan Ylldız, F., \& Yılmaz, A. (2021). Parent-teacher communication and parental expectations in the assessment process in Turkish preschool settings. International Journal of Primary, Elementary and Early Years Education, 49(6), 761-775. https://doi.org/10.1080/03004279.2020.1861049.

Plano Clark, V. L. (2017). Mixed methods research. Journal of Positive Psychology, 12(3), 305-306. https://doi.org/10.1080/17439760.2016.1262619.

Pramesti, G. (2018). Mahir Mengolah data Penelitian Dengan Spss 25. elex media.

Pratama, F., Firman, \& Neviyarni. (2019a). Edukatif : Jurnalilmupendidikan Pengaruh Motivasi Belajar Ipa Siswa Terhadap Hasil. Edukatif: Jurnalilmupendidikan, 1(3), 280-286.

Pratama, F., Firman, \& Neviyarni. (2019b). Pengaruh Motivasi Belajar IPA Siswa Terhadap Hasil Belajar Di Sekolah Dasar Negeri 01. Jurnal Ilmu Pendidikan, 1(3), 280-286. https://doi.org/https://doi.org/10.31004/edukatif.v1i3.63.

Ricardo, \& Meilani, R. I. (2017). Impak Minat dan Motivasi Belajar Terhadap Hasil Belajar Siswa. Jurnal Pendidikan Manajemen Perkantoran, 2(2), 79. https://doi.org/10.17509/jpm.v2i2.8108.

Rosmalina, D., \& Zulyanty, M. (2019). Dukungan Orang Tua Terhadap Motivasi Belajar Siswa Kelas Unggul. Jurnal Gentala Pendidikan Dasar, 4(I), 64-75. https://doi.org/http://onlinejournal.unja.ac.id/index.php/gentala.

Saada, N., \& Magadlah, H. (2021). The meanings and possible implications of critical Islamic religious education. British Journal of Religious Education, 43(2), 206-217. https://doi.org/10.1080/01416200.2020.1785844.

Saerang, I., Tommy, P., \& Christiano, M. (2014). Analisis Terhadap Rasio-rasio Keuangan Untuk Mengukur Profitabilitas Pada Bank-bank Swasta Yang Go Public Di Bursa Efek Indonesia. Jurnal Riset Ekonomi, Manajemen, Bisnis Dan Akuntansi, 2(4), 817-830. https://doi.org/10.35794/emba.v2i4.6490.

Santoso, S. (2019). Menguasai SPSS versi 2. Elex Media Komputindo.

Şemin, F. K. (2019). Competencies of principals in ensuring sustainable education: Teachers' views. International Journal of Evaluation and Research in Education, 8(2), 201-212. https://doi.org/10.11591/ijere.v8i2.18273.

Setiawati, E., Livana, \& Susanti, Y. (2017). Hubungan Konsep Diri Dengan Kualitas Hidup Anak Usia Sekolah Pada Keluarga Buruh Migran Internasional. Indonesian Journal for Health Sciences, 1(2), 21. https://doi.org/10.24269/ijhs.v1i2.628.

Setyani, Zuliyana, F., Rofitrasari, Amelia, N., \& Ahsani, E. L. F. (2021). Analisis Sistem Pendidikan Di Sekolah Indonesia Kuala Lumpur (SIKL) : Perspektif Guru. Jurnal Ilmiah Pendidikan Guru Sekolah Dasar, 14(1), 1-11. https://doi.org/10.33369/pgsd.14.1.70-79.

Simanjuntak, S. Y., Kismartini, Dwimawanti, I. H., \& Hidayatullah, M. A. (2020). Respons Guru Terhadap Kebijakan Pembelajaran Jarak Jauh Selama Pandemi Covid-19. Jurnal Ilmiah Pendidikan Citra Bakti, 7(2), 125-136. https://doi.org/10.38048/jipcb.v7i2.108.

Speight, L., Crawford, K., \& Haddelsey, S. (2018). Towards measures of longitudinal learning gain in uk higher education: The challenge of meaningful engagement. Higher Education Pedagogies, 3(1), 196-218. https://doi.org/10.1080/23752696.2018.1476827.

Sukendar, A., Usman, H., \& Jabar, C. S. A. (2019). Teaching-loving-caring (asah-asih-asuh) and semi-military education on character education management. Cakrawala Pendidikan. https://doi.org/10.21831/cp.v38i2.24452.

Sumarsono, R. B., Imron, A., Wiyono, B. B., \& Arifin, I. (2019). Strategi Kepala Sekolah Dalam Mengoptimalkan Partisipasi Orangtua Untuk Meningkatkan Kualitas Sekolah. JMSP: Jurnal Manajemen Dan Supervisi Pendidikan, 4(1). https://doi.org/10.17977/um025v4i12019p007.

Tamboto, H., Tambingon, H. N., Lengkong, J. S. ., \& Rotty, V. N. J. (2021). The Involvement of Students' Parents in Organizing the Learning from Home at Elementary Schools in Tomohon City. Asia Pacific Journal of Management and Education, 4(1), 35-51. https://doi.org/10.32535/apjme.v4i1.1044.

Triwardhani, I. J., Trigartanti, W., Rachmawati, I., \& Putra, R. P. (2020). Strategi Guru dalam membangun 
komunikasi dengan Orang Tua Siswa di Sekolah. Jurnal Kajian Komunikasi, 8(1), 99. https://doi.org/10.24198/jkk.v8i1.23620.

Ulfat, F. (2020). Empirical research: Challenges and impulses for Islamic religious education. British Journal of Religious Education, 42(4), 415-423. https://doi.org/10.1080/01416200.2020.1711513.

Utari, L., Kurniawan, \& Fathurrochman, I. (2020). Peran Guru Pendidikan Agama Islam dalam Membina Akhlak Peserta Didik Autis. JOEAI (Journal of Education and Instruction), 3(1), 75-89. https://doi.org/10.31539/joeai.v3i1.1304.

Wang, K. Y. C. (2020). Information Behavior of Parents during COVID-19 in Relation to Their Young Schoolage Children's Education. Serials Librarian, 79(1-2), 62-77. https://doi.org/10.1080/0361526X.2020.1806179.

Wegawati, N. P., Tastra, D. K., \& Kusmariyatni, N. (2016). Pengaruh Pendekatan Starter Eksperimen Berbantuan Media Konkret terhadap Hasil Belajar IPA Siswa Kelas 5. E-Journal PGSD Universitas Pendidikan Ganesha, 4(1), 1-9. https://doi.org/10.23887/jjpgsd.v4i1.7334.

Winata, R., Friantini, R. N., Studi, P., Matematika, P., Rani, J. A., Barat, K., \& Belajar, P. (2019). Pengaruh Motivasi Belajar Terhadap Prestasi Belajar Matematika Siswa Kelas VIII SMPN 1 Kuala Behe. JIPM (Jurnal Ilmiah Pendidikan Matematika), 7(2), 85-92. https://doi.org/10.25273/jipm.v7i2.3663.

Wiyani, N. A. (2020). Implementation of a Character Education Strategy in the Perspective of Permendikbud Number 23 of 2015 at Raudhatul Athfal. Tarbawi: Jurnal Keilmuan Manajemen Pendidikan, 6(02), 141. https://doi.org/10.32678/tarbawi.v6i02.2934.

Zarić, J., Hasselhorn, M., \& Nagler, T. (2021). Orthographic knowledge predicts reading and spelling skills over and above general intelligence and phonological awareness. European Journal of Psychology of Education, 36(1), 21-43. https://doi.org/10.1007/s10212-020-00464-7.

Zijlstra, H., van Bergen, E., Regtvoort, A., de Jong, P. F., \& van der Leij, A. (2021). Prevention of reading difficulties in children with and without familial risk: Short- and long-term effects of an early intervention. Journal of Educational Psychology, 113(2). https://doi.org/10.1037/edu0000489. 